\title{
Unravelling the potential of halophytes for marine integrated multi-trophic aquaculture (IMTA) - a perspective on performance, opportunities and challenges
}

\author{
Marco Custódio ${ }^{1, *}$, Sebastian Villasante $^{2}$, Javier Cremades $^{3}{ }_{\text {, Ricardo Calado }}{ }^{1}$, \\ Ana I. Lillebø ${ }^{1}$
}

${ }^{1}$ Department of Biology \& CESAM \& ECOMARE, University of Aveiro, Campus Universitário de Santiago, 3810-193 Aveiro, Portugal

${ }^{2}$ Faculty of Political Sciences, University of Santiago de Compostela, 15782 Santiago de Compostela, A Coruña, Spain

${ }^{3}$ Centre for Advanced Scientific Research (CICA), University of A Coruña, 15071 A Coruña, Spain

\begin{abstract}
The present study critically analyses peer-reviewed literature addressing the potential of halophytes to remediate nutrient-rich effluents from marine and coastal aquaculture, as well as the potential for their economic valorization, from human consumption to an untapped source of valuable secondary metabolites with pharmaceutical potential. The growing body of evidence discussed in this review supports the perspective that halophytes can become a new source of nutrition and other high-value compounds and be easily incorporated into saltwater-based integrated multi-trophic aquaculture (IMTA) systems. In this context, halophytes act as extractors of dissolved inorganic nutrients, primarily nitrogen and phosphate, usually wasted in marine aquaculture farms. Phytoremediation using halophytes has been proven to be an efficient solution, and several ways exist to couple this practice with land-based marine aquaculture systems, namely through constructed wetlands and aquaponics. Focusing research on ecosystem-based approaches to aquaculture production will provide valuable data for producers and policy makers in order to improve decision making towards a sustainable development of this economic sector. Ecointensification of aquaculture through IMTA will potentially increase the overall productivity and resilience of the sector, and halophytes, in particular, are on the verge of becoming key players for the diversification and promotion of land-based IMTA. This work specifically documents the uncharted potential of Halimione portulacoides, an important halophyte in European salt marsh ecosystems, as a new extractive species for IMTA.
\end{abstract}

KEY WORDS: Sustainable aquaculture - Bioremediation - Dissolved nutrients - Coastal IMTA · Saltwater aquaponics $\cdot$ Blue growth $\cdot$ Circular economy

\section{INTRODUCTION}

Aquaculture has experienced a fast and steady growth over the last decades, achieving a $7.5 \%$ annual growth rate between 1990 and 2009, significantly surpassing all other livestock sectors (Troell et

*Corresponding author: mfc@ua.pt al. 2014). Part of such rapid development is explained by the overexploitation of fish stocks that limits the supply of wild marine fish (FAO 2016), leaving aquaculture as the only alternative to meet an ever growing demand for seafood. Nonetheless, the fast development of the industry, which already supplies $50 \%$

() The authors 2017. Open Access under Creative Commons by Attribution Licence. Use, distribution and reproduction are unrestricted. Authors and original publication must be credited. 
of global seafood, has brought concerns about the extent of its environmental impact (FAO 2016). Organic waste produced in fish farms negatively impacts aquatic ecosystems by modifying water biochemistry and ecological interactions (Troell et al. 2014). Particulate organic matter and dissolved inorganic nutrients, especially nitrogen $(\mathrm{N})$ and phosphorus (P) forms, can promote water eutrophication and dramatically change sediment chemistry and associated benthic biodiversity (Sanz-Lázaro et al. 2011, Sarà et al. 2011, Valdemarsen et al. 2012, Bannister et al. 2014). In this way, new integrative, non-linear production methods are necessary to reduce the ecological impact of fish farms. To promote such measures, the EU (through the Marine Strategy Framework Directive, Water Framework Directive, Circular Economy strategy and the Blue Growth strategy) demands new approaches towards sustainable aquaculture practices and waste management and re-utilization (European Commission 2012, 2015, Science for Environment Policy 2015, European Environment Agency 2016).

Integrated multi-trophic aquaculture (IMTA) systems have been recently studied and endorsed by scientists as a real sustainable solution for the industry (Troell et al. 2009, Barrington et al. 2010, Abreu et al. 2011, Chopin 2015, 2017, Fang et al. 2016, Granada et al. 2016) Conceptually, IMTA is based on an ecosystem approach framework, where nutrients wasted on one trophic level, in particulate and dissolved forms, are redirected to downstream trophic levels to be filtered and/or extracted by capable organisms and utilized for growth. By performing this way, waste is reduced, productivity is increased (Hughes \& Black 2016), and the overall resilience of the global food system is improved (Troell et al. 2014). The integration of additional trophic levels greatly depends on the type of aquaculture systems in terms of production intensity and water salinity. Freshwater aquaculture allows for the integration of salt-sensitive extractive species such as vegetables commonly farmed in agriculture, often by coupling fish-rearing systems with hydroponics, an activity known as aquaponics (Graber \& Junge 2009, Somerville et al. 2014, dos Santos 2016). However, a major portion $(\sim 5 / 6)$ of European aquaculture is marine and coastal water-based (FAO 2016), and extractive species need to be salt-tolerant to remediate saline effluents. Important research already exists concerning the use of organisms such as shellfish and seaweeds in marine IMTA (Neori et al. 2004, Troell et al. 2009, Chopin 2015), yet an underrated group of salt-tolerant plants could take IMTA to another level - halophytes.
This paper aims to contextualize the importance of halophytes in a new era of sustainable aquaculture and, particularly, elaborate on the potential of Halimione portulacoides (L.) Aellen (Fig. 1), a low C3 shrub from the family Chenopodiaceae (order Caryophyllales), as a bioremediator and valuable co-product for IMTA. This view is supported by both biological and ecological traits, as demonstrated through a critical survey of available peer-reviewed literature. This species was chosen due to its wide geographic distribution, namely in European salt marshes where it colonizes low and mid-marsh areas (Waisel 1972, Castroviejo 1990); it is also a key species characterizing the 'Mediterranean and thermo-Atlantic halophilous scrubs' habitat, classified in the scope of EU Habitats Directive (Council Directive 92/43/EEC; European Commission 1992) and protected in several EU Natura 2000 sites (European Commission
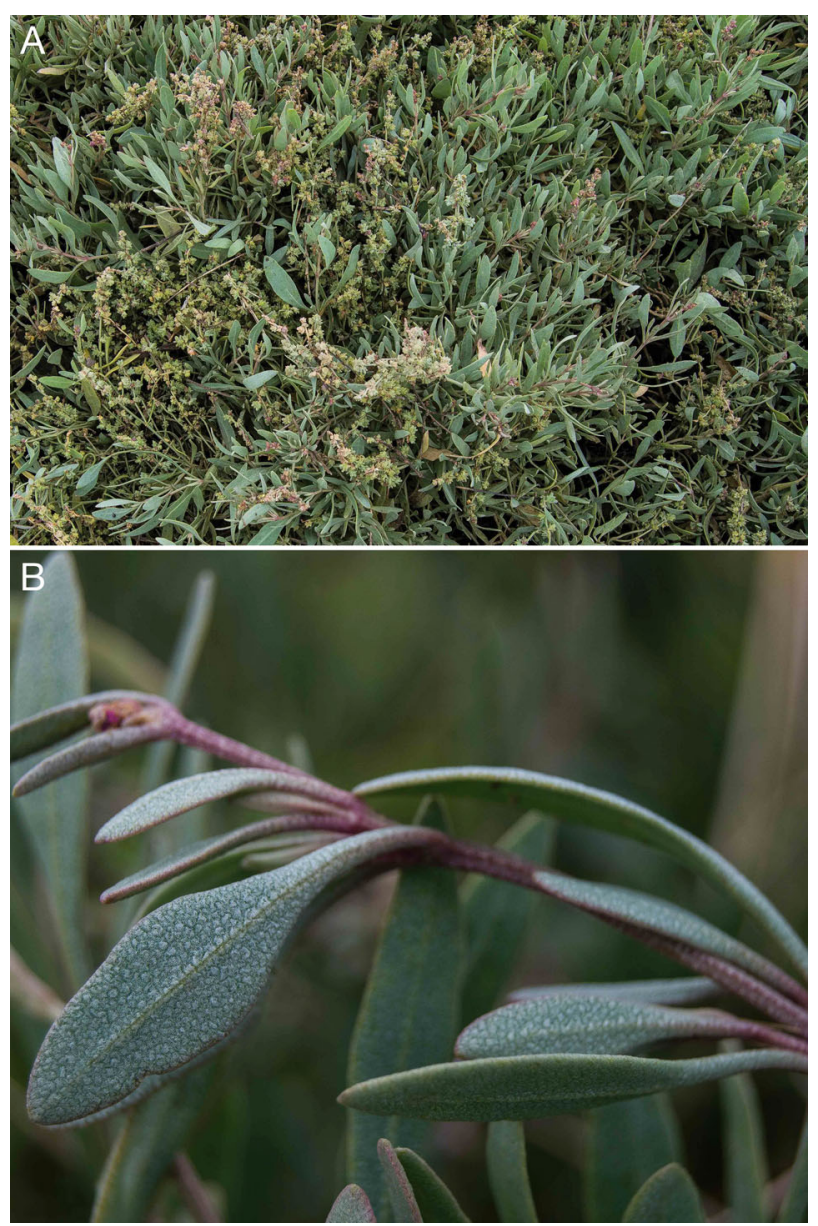

Fig. 1. Halimione portulacoides: (A) top view of a specimen and (B) detail of the leaves (edible part), showing their succulence and epidermal bladders. Location: section of the Aveiro Lagoon at Gafanha da Boa-Hora, Aveiro, Portugal (40³2' 55.9" N, 8 46' 05.6" W) (Photos: M. Custódio) 
2013). The background knowledge on the species' ecology by some of authors and its ample presence in Portuguese salt marshes (e.g. Sousa et al. 2008, 2010, 2011, Válega et al. 2008a,b), particularly in the Aveiro region, was another reason for selecting this species, as was the fact that it is a perennial and evergreen halophyte, which removes the need for manipulation of the life cycle, as happens with annual plants (e.g. Salicornia europaea s.l.). Plus, the species has potential for integration and valorization in the context of the aquaculture sector in regions where it naturally occurs, being suitable for IMTA solutions compatible with marine protected areas (Chopin 2017). Within this context, $H$. portulacoides could diversify the offer of autochthonous halophytes within the market of sea vegetables.

\section{HALOPHYTES - THE NEW PLAYERS IN SUSTAINABLE MARINE AQUACULTURE}

Halophytes are salt-tolerant plants that complete their life cycle in saline environments, to which they are highly adapted (Glenn et al. 1999, Flowers \& Colmer 2008, Panta et al. 2014). A generally accepted definition for halophytes sets a salt concentration tolerance of at least $200 \mathrm{mM} \mathrm{NaCl}$, as long as the remaining environmental conditions are within the natural environment (Flowers et al. 1986). These unconventional crop plants have been overlooked by the food production sector, which mainly produces salt-sensitive vegetable species, i.e. glycophytes, which depend on freshwater irrigation for optimum yields. Nonetheless, humans in coastal communities within Europe and North America have consumed edible halophytes for centuries. For example, the salty leaves of 'sea purslane' (common name given to plants from the sister genera Atriplex and Halimione; see Kadereit et al. 2010) have been appreciated in some European countries and are now collected from the wild by professional foragers and sold in specialized online platforms (e.g. online on Farmdrop and Fine Food Specialist, UK), for local restaurants and gourmet cuisine (Barreira et al. 2017). The most recent case of emergent success is Salicornia L. spp., which have shown high levels of omega-3 polyunsaturated fatty acids and $\beta$-carotene antioxidants, and are already being produced in commercial-scale agriculture operations in the USA and Europe (Boer 2008, Lu et al. 2010, Ventura \& Sagi 2013, Panta et al. 2014, Ventura et al. 2015). Moreover, halophytes can also be used as bioenergy sources (Abideen et al. 2011, Ventura et al. 2015, Sharma et al. 2016) and nutraceutical products, such as mineral-rich herbal salts (Kim \& Kim 2013).

Halophytic species have developed remarkable physiological traits to succeed in highly saline environments where the majority (>90\%) of plant species would perish (Flowers et al. 2010). These adaptations allow for the retention of water, protection of enzymatic machineries and maintenance of homeostasis (Flowers \& Colmer 2008, Flowers et al. 2010, Ksouri et al. 2012). A number of metabolites are biosynthesized by these plants (Aquino et al. 2011, Maciel et al. 2016), and many display bioactivity against oxidative stress, microbes, inflammations and tumors (Boughalleb \& Denden 2011, Ksouri et al. 2012, Buhmann \& Papenbrock 2013a, Rodrigues et al. 2014), which emphasizes their potential to be used by the pharmaceutical industry.

The integration of halophytes with economic potential in marine aquaculture systems to remediate nutrient-rich effluents and process water has received growing attention by research groups interested in sustainable aquaculture, and a developing body of knowledge is already available, indicating promising results (Buhmann \& Papenbrock 2013b, de Lange et al. 2013, Shpigel et al. 2013, Waller et al. 2015). Halophytes can be integrated in IMTA systems through modules that allow for sustained plant growth and water (re)circulation, and the 2 main structures used for that purpose are usually constructed wetlands (CWs) and aquaponics systems. CWs have proven to be efficient at removing a wide range of organic and inorganic substances from different wastewater sources (Verhoeven \& Meuleman 1999, Imfeld et al. 2009, Vymazal 2010, 2011, Shelef et al. 2013) including aquaculture (de Lange et al. 2013, Turcios \& Papenbrock 2014, Carballeira et al. 2016). Aquaponics systems, on the other hand, have been mostly experimented with freshwater setups (Somerville et al. 2014, dos Santos 2016). Both systems have the potential to be used as growth modules for halophytes and support their integration in marine aquaculture activities (Turcios \& Papenbrock 2014).

\section{SURVEY OF SCIENTIFIC LITERATURE}

A stepwise review of available scientific literature reporting the utilization of halophytes for remediation of marine aquaculture waters was performed, followed by a special focus on Halimione portulacoides, with emphasis on its biology, ecology and biochemistry. The different steps of the process carried 


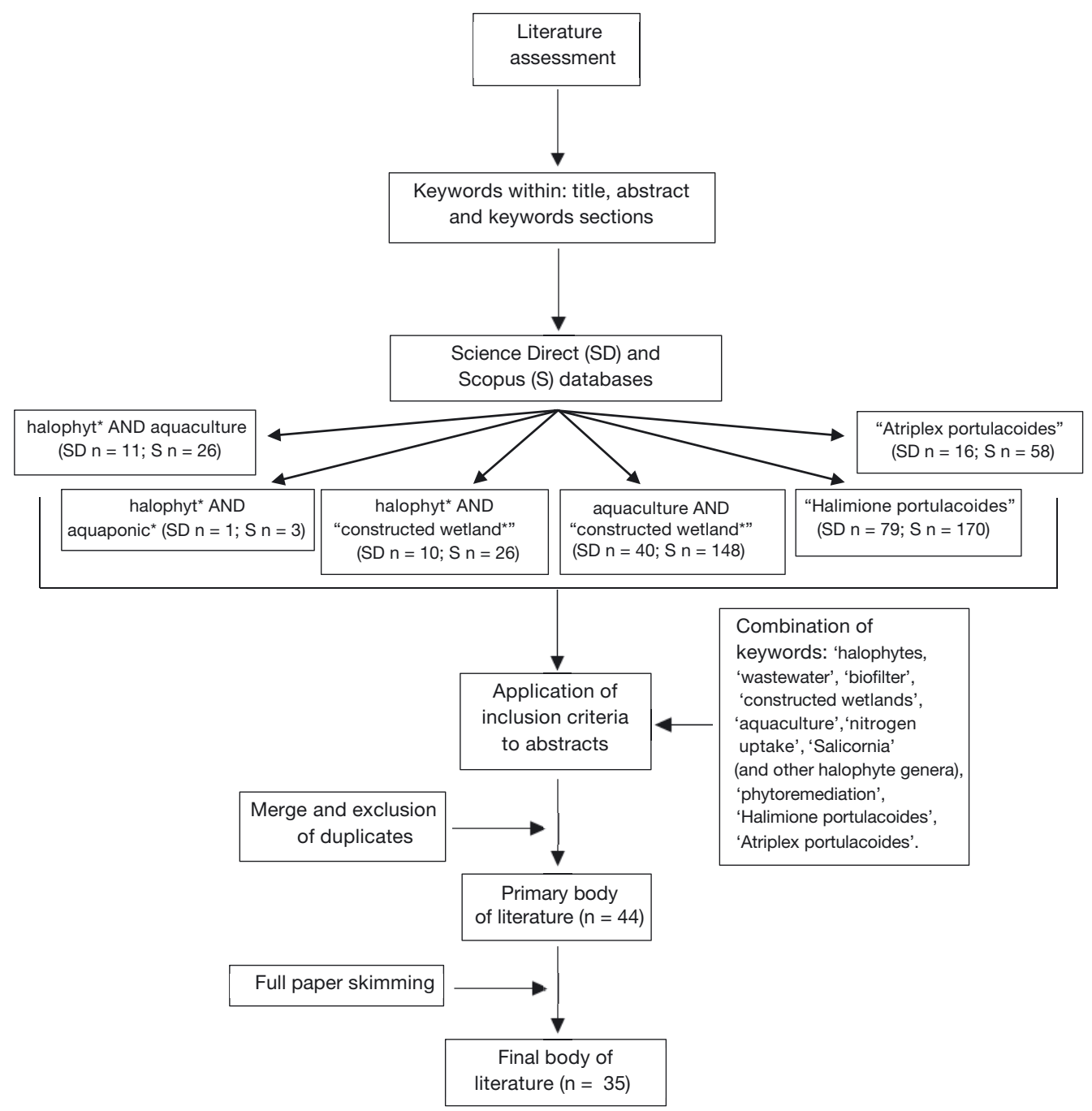

Fig. 2. Process employed for the selection of relevant literature

out for the selection of relevant literature is outlined in Fig. 2. A first assessment was conducted using Science Direct (SD) and Scopus (S) digital databases by searching for specific keywords within the title, abstract and key words sections of papers available online by November 2016. The search term 'Atriplex portulacoides' was included in the assessment as it is a homotypic synonym of $H$. portulacoides, and some authors opted for that name in their publications. On a subsequent assessment, the abstracts of all publications were surveyed, and the final selection of articles was imported into Mendeley ${ }^{\mathrm{TM}}(\mathrm{n}=44)$. All of these papers were fully read, and from these, 35 peer-reviewed articles were selected as the most relevant for the present review (the complete list of the selected publications is provided in Table S1 in the Supplement at www.int-res.com/articles/suppl/q009 p445_supp.pdf). Selected articles had to fulfill the fol- lowing criteria: (1) include experiments using halophytes as extractive species for saltwater aquaculture effluents and (2) address halophytes growing in CWs and/or aquaponics/hydroponics systems or (3) focus the research on $H$. portulacoides biology, ecology and/or biochemistry.

\section{HALOPHYTES IN AQUACULTURE: FACTS AND FIGURES}

Concerning the use of halophytes as biofilters for aquaculture, 15 original research articles and 4 reviews were selected, where the integration and performance of several species were evaluated and discussed. The criteria for species selection, where referred, were based on local availability, salinity tolerance and economic potential. In total, 22 halophyte 
species (17 genera) were tested, and full species names, number of aquaculture remediation studies per plant species and references are represented in Fig. 3.

The most studied halophyte to date was Aster tripolium (5 studies; including the homotypic synonym Tripolium pannonicum), followed by Salicornia europaea (4 studies), Phragmites australis (3 studies) and $S$. dolichostachya (2 studies). All other species have been addressed only once (Fig. 3). The growing modules for halophytes were either hydroponics- or

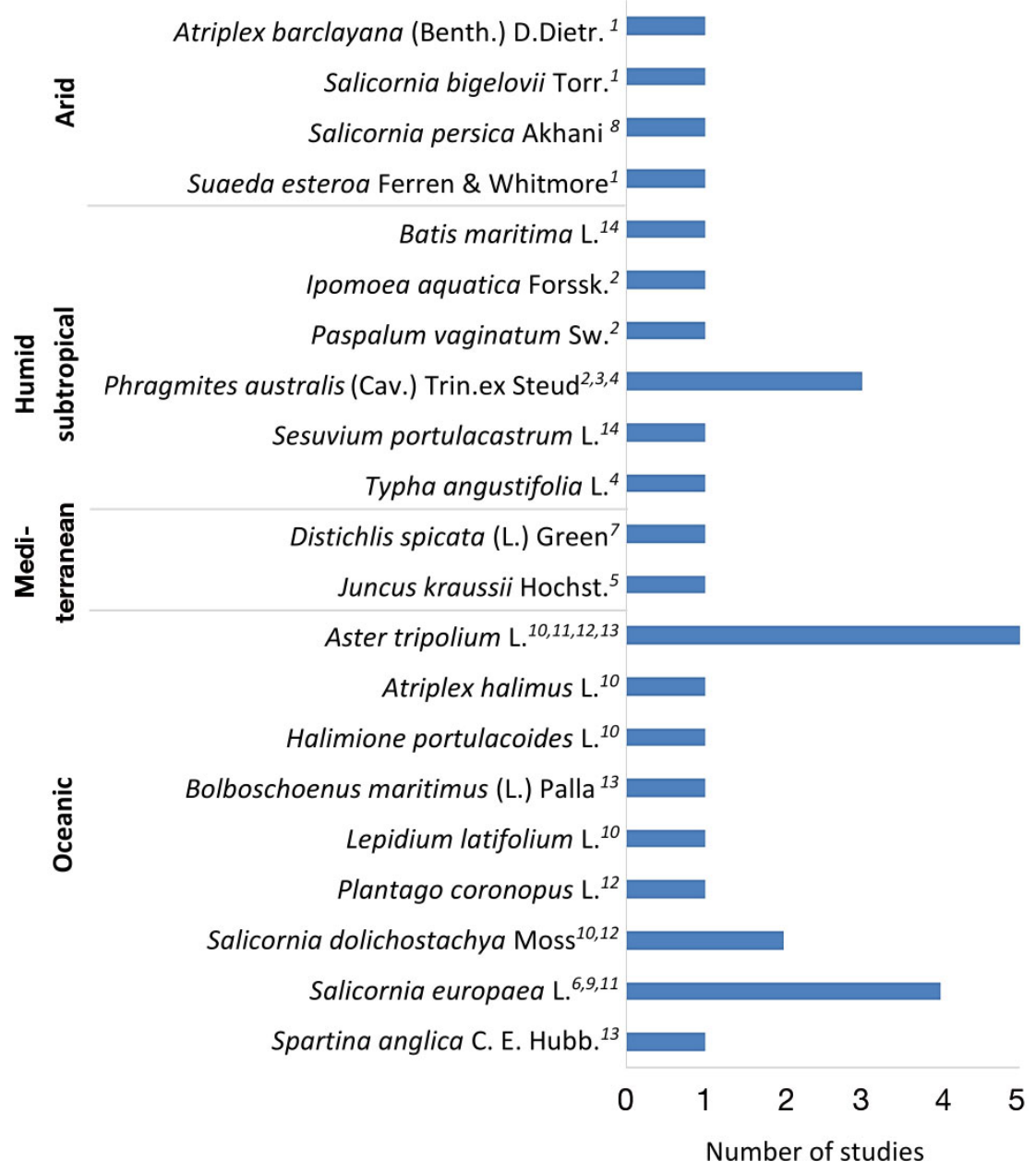

Fig. 3. Number of studies per halophyte species where phytoremediation was tested and growth performances evaluated upon irrigation with saline aquaculture wastewater. The geographic location where each experimental trial took place was ranked following the Köppen climate classification. ${ }^{1}$ Brown et al. (1999); ${ }^{2}$ Lin et al. (2002b); ${ }^{3}$ Lin et al. (2003); ${ }^{4}$ Lin et al. (2005); ${ }^{5}$ Lymbery et al. (2006); ${ }^{6}$ Webb et al. (2012); ${ }^{7}$ Lymbery et al. (2013); ${ }^{8}$ Shpigel et al. (2013); ${ }^{9}$ Webb et al. (2013)i ${ }^{10}$ Buhmann et al. (2015); ${ }^{11}$ Quintã et al. $(2015 a, b) ;{ }^{12}$ Waller et al. (2015); ${ }^{13}$ De Lange \& Paulissen $(2016) ;{ }^{14}$ Boxman et al. (2017). Notes: (i) Aster tripolium as Tripolium pannonicum (Jacq.) Dobrocz. in Buhmann et al. (2015) and Waller et al. (2015); (ii) Halimione portulacoides as Atriplex portulacoides L. in Buhmann et al. (2015); (iii) Bolboschoenus maritimus as Scirpus maritimus L. in De Lange \& Paulissen (2016) substrate-based, and it appears that the choice of medium depends on the type of intensification being employed for the production of the target fish species (semi-intensive vs. intensive/recirculating aquaculture system [RAS]), as well as halophyte species nd biofilter main purpose (wastewater treatment vs. plant biomass production) (Buhmann \& Papenbrock 2013b, Buhmann et al. 2015, Chen \& Wong 2016). armed species from which the effluents originated included different fish and shrimp, and in some studies, artificial solutions mimicking the organic load of aquaculture effluents were used (Buhmann et al. 2015, Quintã et al. 2015a, de Lange \& Paulissen 2016). Farmed species included Chanos chanos Forssk., 1775 (Lin et al. 2002b), Dicentrarchus labrax L., 1758 (Quintã et al. 2015b, Waller et al. 2015), Oncorhynchus mykiss Walbaum, 1792 (Lymbery et al. 2006, 2013), Oreochromis sp. Günther, 1889 (Brown et al. 1999), Penaeus vannamei Boone, 1931 (Lin et al. 2003, 2005, Webb et al. 2012, 2013), Solea senegalensis Kaup, 1858 (Webb et al. 2012), Sparus aurata L., 1758 (Shpigel et al. 2013) and Xiphophorus sp. Heckel, 1848 (Boxman et al. 2017). Effluents originating from the culture of freshwater species were salinized by adding $\mathrm{NaCl}$ prior to the irrigation of halophytes. The experiments were performed in diverse geographic regions and climates (Fig. 4): the arid climates of southern Israel (Shpigel et al. 2013) and southwestern USA (Brown et al. 1999), the humid subtropical regions of Taiwan (Lin et al. 2002b, 2003, 2005) and southeastern USA (Boxman et al. 2017), the oceanic climate of northwestern Europe (Webb et al. 2012, 2013, Buhmann et al. 2015, Quintã et al. 2015a, Waller et al. 2015, de Lange \& Paulissen 2016) and the Mediterranean climate of southwestern Australia (Lymbery et al. 2006, 2013). Yet, the diversity of studies is still low and additional studies with endemic species in different climate regions are needed. Concerning the economic valorization of plant biomass, researchers referred to the potential of some species to be used as 


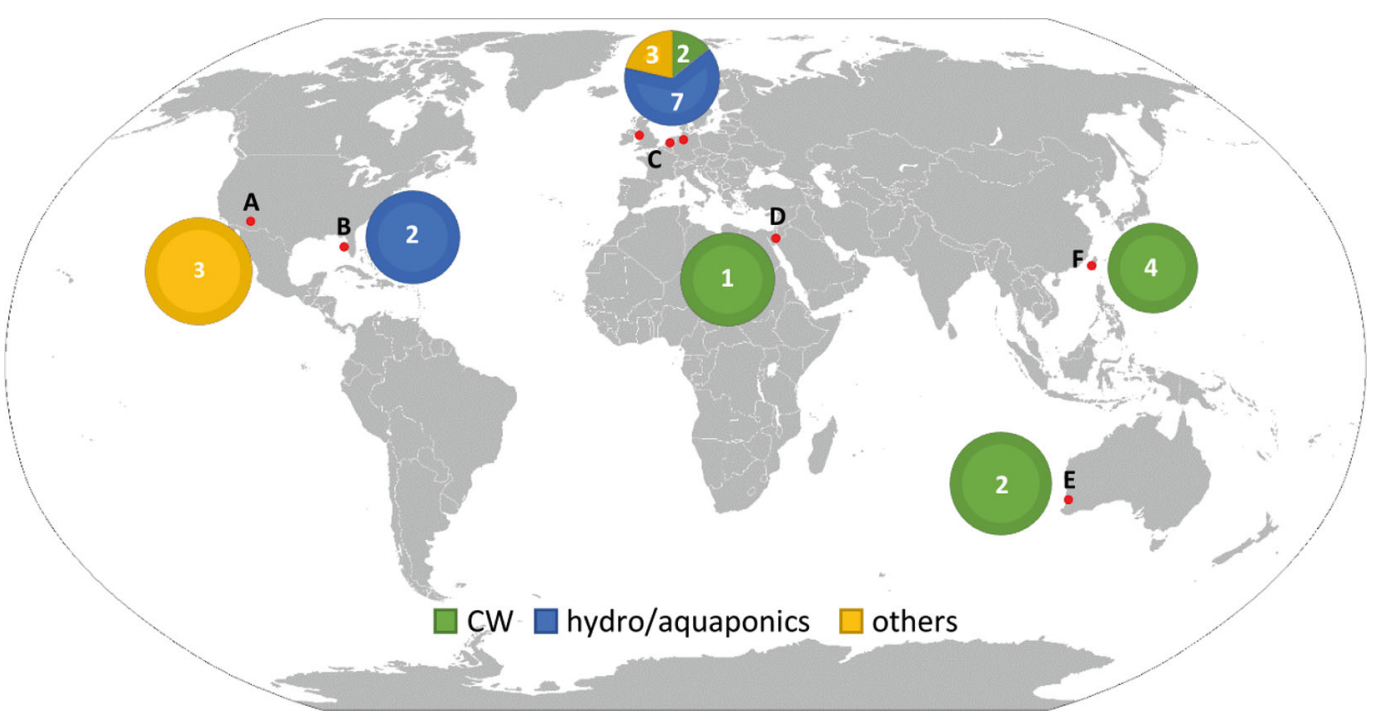

Fig. 4. Geographic locations of previous experiments using halophytes as aquaculture effluent remediators (red dots). Pie charts represent plant-growing systems (CW: constructed wetland; hydro/aquaponics and others [pot-planted or lysimeter]) used in each region in relation to the number of species tested (white numbers). Regions and species (from left to right): (A) South Arizona (USA) - Atriplex barclayana; Salicornia bigelovii and Suaeda esteroa; (B) Florida (USA) - Batis maritima and Sesuvium portulacastrum; (C) Northern Europe - hydro/aquaponics: Aster tripolium, Atriplex halimus, Halimione portulacoides, Lepidium latifolium, Plantago coronopus, Salicornia dolichostachya and Salicornia europaea; CW: A. tripolium and S. europaea; others: A. tripolium, Bolboschoenus maritimus and Spartina anglica; (D) Israel - Salicornia persica; (E) Southwestern Australia - Distichlis spicata and Juncus kraussii; (F) Taiwan - Ipomoea aquatica, Paspalum vaginatum, Phragmites australis and Typha angustifolia. Map editing software: ArcGIS

food for human consumption (e.g. Salicornia spp., A. tripolium and Halimione portulacoides; Lu et al. 2010, Webb et al. 2012, Isca et al. 2014, Buhmann et al. 2015, Quintã et al. 2015a), as forage for livestock (e.g. Suaeda esteroa and Distichlis spicata; Brown et al. 1999, Lymbery et al. 2013, Panta et al. 2014), as oil sources (e.g. Salicornia spp. seeds; Brown et al. 1999, Weber et al. 2007, Sharma et al. 2016) and as sources of extracts with pharmacological applications (Ksouri et al. 2012, Buhmann \& Papenbrock 2013a).

In Table 1, data from experiments using CWs is displayed concerning the performance of different halophytes in removing $\mathrm{N}$ and $\mathrm{P}$ from wastewater. Due to the reduced number of experiments involving hydroponic/aquaponic setups (Buhmann et al. 2015, Quintã et al. 2015a, Waller et al. 2015, Boxman et al. 2017), out of which only 2 included $N$ and P removal efficiencies, and due to several differences in surveyed variables to allow a direct comparison of the data with those reported from CW set ups, studies addressing hydroponic/aquaponic setups were not included in Table 1. For easier comparison between experiments using CWs and whenever possible, values reported on the different studies were converted to a common unit. Due to the variability in environmental and biological factors between experimental conditions (e.g. salinity, substrate, nutrient concen- tration, water volume, retention time, duration of the experiment, plant density, age of plants and climatic conditions such as temperature and light) results cannot be directly compared. However, despite the existing variability in terms of nutrient removal, which seems to depend on system design, flow regime, nutrient concentration and species (Buhmann \& Papenbrock 2013b), not all setups per se are equally effective for nutrient removal, taking into account the specific objectives established for each CW. N removal capacity attained around $90 \%$ or more in 4 of the studies that were surveyed (Brown et al. 1999, Lin et al. 2002b, Webb et al. 2012, Lymbery et al. 2013), and only 1 experiment reported a low $\mathrm{N}$ removal capacity (11\%) (de Lange \& Paulissen 2016). While in some of the studies $P$ removal was close to $100 \%$ (e.g. Brown et al. 1999), in 1 of the experiments reported, P removal was only 13\% (Shpigel et al. 2013). Fig. 5 illustrates the performance of different halophyte species, in terms of $\mathrm{N}$ and $\mathrm{P}$ removal efficiency attained under different experimental conditions (based on data summarized in Table 1). Although results should not be directly compared, the key point is to highlight the phytoremediation service provided by halophytes in CWs, as most of them fulfilled the objectives under the tested conditions. 


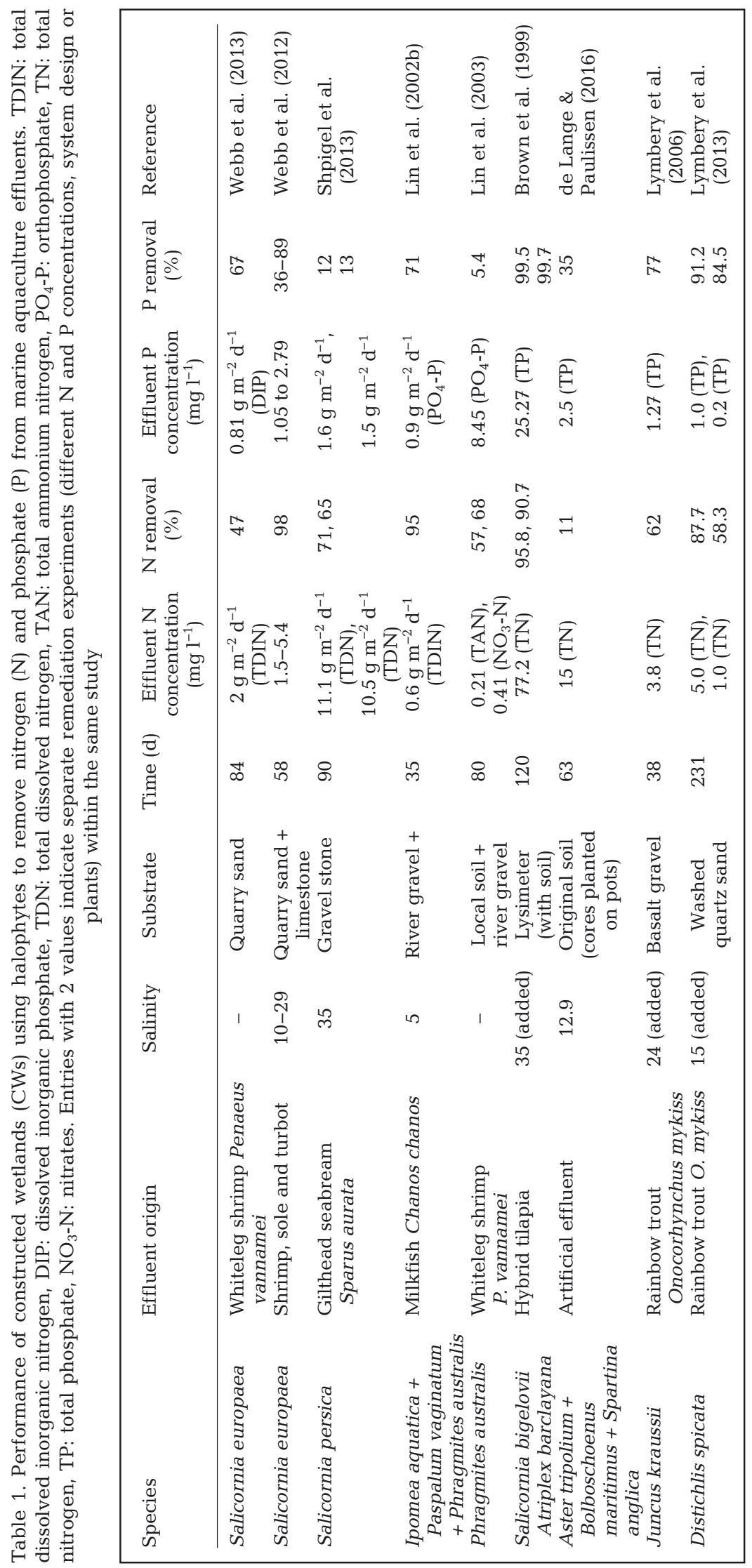

\section{CHALLENGES AND OPPORTUNITIES FOR INTEGRATING HALOPHYTES IN IMTA}

The eutrophication of water bodies has become a major issue in modern aquaculture due to the intensification and expansion of production and increased use of high-protein pelleted feeds (Edwards 2015). It was estimated that in conventional aquaculture, fish assimilate only 25-40\% of the whole $\mathrm{N}$ and $\mathrm{P}$ available in their diets (Lupatsch \& Kissil 1998, Wang et al. 2012), while the rest is wasted into effluent water through feed lixiviation and fish excretion/metabolism. Yet, nutrient-rich wastes could be redirected to trophic levels capable of assimilating these nutrients and convert them into biomass with economic value, while simultaneously reducing water pollution. Given that food waste is an increasing concern in Europe, the potential of this waste redirection can help the implementation of the EU plans for a circular economy, in which the challenge of transition towards reduction of waste and sustainable resource efficiency are key to develop a competitive EU economy (European Commission 2015). Technological improvements and adaptation processes of fish farms could transform aquaculture production, creating new windows of opportunity for a sustainable Blue Growth of European coastal areas (European Commission 2012).

The integration of CWs and aquaponics systems to grow halophytes in IMTA are relatively new concepts that deserve scientific scrutiny in order to evaluate their potential for large-scale application. In the case of CWs, plants function as a solid biological filter where nitrification and denitrification processes occur and nutrients are restrained and extracted from the effluent by the plants, soil microorganisms and substrate (Webb et al. 2012, 2013, Shpigel et al. 2013). In aquaponics, the system necessarily requires an independent upstream biofilter to promote nitrification processes. This is essential in 'free-floating' configurations (e.g. floating rafts [also known as deep-water culture] and nutrient-film technique), while systems using inert growing 


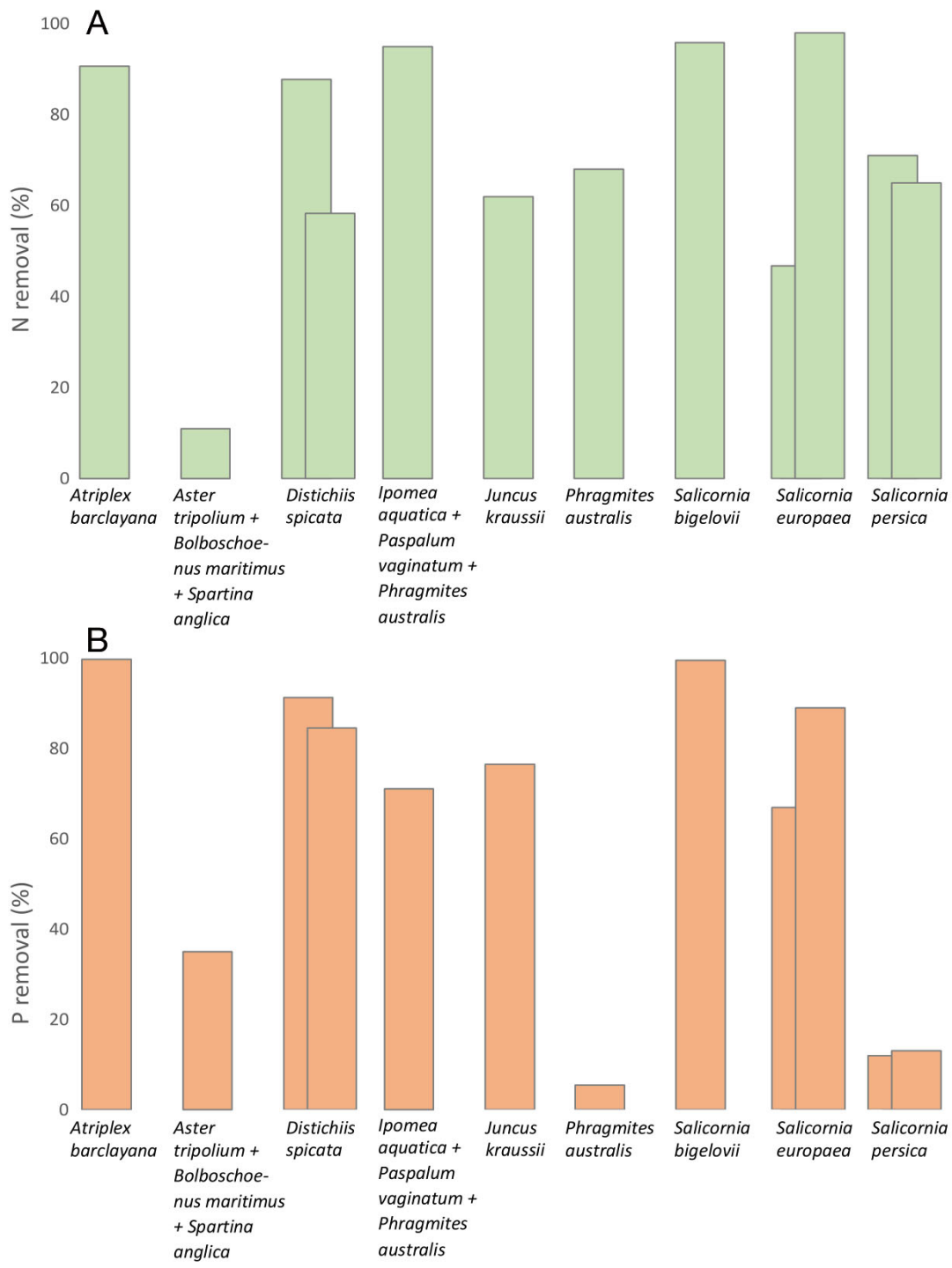

Fig. 5. Average percentage of (A) $\mathrm{N}$ removal and (B) $\mathrm{P}$ removal from saline aquaculture effluents by halophyte species planted in constructed wetlands (CWs; according to data reported in Table 1). Overlapping bars correspond to different studies using the same species

media, such as expanded clay, allow nitrifying bacteria to establish in the solid surface (Buhmann et al. 2015, Waller et al. 2015, Boxman et al. 2017). Buhmann \& Papenbrock (2013b) reviewed some studies that used halophyte CWs as biofilters, showing promising results yet referring to the need for more comprehensive research. To date, the halophytes that received most of the attention, including in agriculture studies, were Salicornia and Sarcocornia A.J. Scott, which exhibited promising results in terms of growth rates and phytoremediation (Brown et al. 1999, Ventura et al. 2011a,b, Webb et al. 2012, 2013, Katschnig et al. 2013, Ventura \& Sagi 2013). Other species, including Aster tripolium, Plantago corono- pus, Lepidium latifolium, Halimione portulacoides and Atriplex halimus, also demonstrated good potential, as already summarized above. Nonetheless, a great variability in results is undeniable and these are most likely due to variable experimental conditions, species-specific traits, system design and the lack of standardized research methods. More data need to be generated under standardized conditions to evaluate which are the most suitable halophytes for IMTA in order to achieve a more cohesive and robust body of knowledge.

The variables that need to be studied concerning the selection of the best halophyte plants for IMTA inlclude salinity tolerance, macro- and micro-nutrient requirements, light and hydraulic regimens, plant density and the potential for economic valorization (Verhoeven \& Meuleman 1999, Vymazal 2010, Buhmann \& Papenbrock 2013b, Buhmann et al. 2015). For example, in order to investigate the relevance of plant density, Salicornia europaea was grown at 10000 and 200 plants $\mathrm{m}^{-2}$ in CWs, with no significant differences in nutrient removal; up to $85 \%$ of total dissolved inorganic nitrogen (TDIN) was removed, with a maximum removal rate of $1.5 \mathrm{~g} \mathrm{~N} \mathrm{~m}^{-2} \mathrm{~d}^{-1}$ (Webb et al. 2013). Previous observations have shown even higher removal rates (up to $100 \%$ ) of TDIN (Brown et al. 1999, Webb et al. 2012). Some studies stated that the majority of $\mathrm{N}$ removal results from microbial processes and, to a lesser degree, from plant uptake (Lin et al. 2002a, Hadad et al. 2006), but studies with certain species of halophytes advocate otherwise (Webb et al. 2012, 2013). Recently, Quintã et al. (2015b) concluded that hydroponically grown $S$. europaea and A. tripolium could assimilate dissolved organic nitrogen (DON, specifically alanine- $\mathrm{N}$ and trialanine- $\mathrm{N}$ ), suggesting that DON removal should also be taken into consideration in phytoremediation of wastewater. Other authors also concluded that some halophytes, namely Phragmites australis and Spartina alterniflora, seem to directly assimilate both inorganic and organic forms of $\mathrm{N}$ (Mozdzer et al. 2010). In terms of dissolved 
inorganic phosphates (DIP), a CW employing $S$. europaea was able to perform a removal of up to $89 \%$; yet, it is commonly accepted that plants play a small role in phosphate removal, as it is assumed that most of the elimination recorded is achieved through adsorption to the substrate (Lüderitz \& Gerlach 2002, Webb et al. 2012, 2013).

While CWs and aquaponics systems can both be used to remediate wastewater and grow halophytic cash crops, they differ in their applicability and purpose. The primary concern of CWs is usually wastewater treatment, where the interplay of many biological and chemical processes results in high removal rates of $\mathrm{N}$ and $\mathrm{P}$, but where only a fraction of these nutrients is taken up by plants (Turcios \& Papenbrock 2014). On the other hand, the main objective of aquaponics is to maximize plant production (Goddek et al. 2015), which is usually the main source of revenue in freshwater aquaponics. Growing halophytes hydroponically would be a reasonable choice for intensive fish-farming using RAS (Buhmann et al. 2015, Waller et al. 2015). These systems can provide high concentrations of $\mathrm{N}$ for plant growth, but parallel nitrifying biofilters are usually necessary to produce the necessary nitrate- $\mathrm{N}$ that is more easily absorbed by plants (Stewart et al. 1973, Jensen 1985). To retain most of $\mathrm{N}$ in nitrate- $\mathrm{N}$ form, anoxic conditions need to be minimized to avoid denitrification, which might occur at very low oxygen concentration $(<10 \%)$, with the consequent release of $\mathrm{N}$ in its atmospheric form (Verhoeven \& Meuleman 1999). Since aquaponics systems are typically well aerated and new optimized aquaponics systems are being designed (Kloas et al. 2015, Goddek et al. 2016), this issue may be easily addressed. In CWs, denitrification processes are more likely to happen due to the fundamental characteristics of the system, which create more oxic-anoxic interactions along the sediment profile, enhancing the coupling between nitrification and denitrification. For that reason, if the main goal is water remediation, CWs are the most cost-effective choice and can be used in both open and closed aquaculture systems. Eventually, as highlighted by Chen \& Wong (2016), a hybrid approach comprised of both types of growing systems would allow to take advantage of both mechanisms, maximizing nutrient removal and plant biomass production.

Regarding biomass yields in both systems, variability is also evident. Using hydroponics growing systems, Boxman et al. (2017) tested the performance of Sesuvium portulacastrum and Batis maritima over $30 \mathrm{~d}$ (initial density of 24 plants $\mathrm{m}^{-2}$ ) and obtained average yields of 0.53 and $0.32 \mathrm{~kg} \mathrm{~m}^{-2}$, respectively.
Waller et al. (2015) grew Salicornia dolichostachya, A. tripolium and $P$. coronopus for $35 \mathrm{~d}$ (initial density of 39 plants $\mathrm{m}^{-2}$ ), with final average yields of 2.70 , 1.25 and $0.83 \mathrm{~kg} \mathrm{~m}^{-2}$, correspondingly. In a CW, Webb et al. (2013) obtained average yields of Salicornia europaea after $21 \mathrm{~d}$ (initial density of 200 plants $\mathrm{m}^{-2}$ ) of $2.2 \mathrm{~kg} \mathrm{~m}^{-2}$. Yield variability might be explained by initial planting densities, availability of physical space for growth and grow-out time to harvest, but species-specific variability is certainly a factor to consider.

The inclusion of halophytes in marine IMTA has been certainly overlooked until recent years due to the lack of a tangible market for its commercialization, when compared with seaweeds, which are commonly studied and used as extractive species in IMTA (Abreu et al. 2011, Chopin 2015, Fang et al. 2016). In fact, global demand for seaweeds is increasing, and the commercial seaweed market is expected to reach US $\$ 22.13$ billion by 2024 (Grand View Research 2016). Another important factor that makes macroalgae more practical and widely chosen for IMTA is that marine IMTA has been mostly implemented in off-shore settings (Troell et al. 2009, Chopin 2015, Fang et al. 2016). As we move towards the implementation of an increasing number of landbased marine IMTA systems (e.g. saltwater aquaponics, RAS coupled with CWs) which have numerous advantages relative to off-shore settings (Gunning et al. 2016), halophytes can be progressively introduced as an extractive species with commercial and socioecologic interest for those systems. A few localized niche markets already exist for halophytes (e.g. gourmet cuisine), and their distinctive nutritional and biochemical composition can further boost their marketability in the near future (Sharma et al. 2016, Barreira et al. 2017).

\section{THE POTENTIAL OF HALIMIONE PORTULACOIDES}

To our knowledge, by November 2016, only 1 study had evaluated the potential of $H$. portulacoides as an extractive species for IMTA. Buhmann et al. (2015) used a hydroponics system and an artificial effluent characterized by a salinity of $15,50 \mathrm{mg} \mathrm{NO}-\mathrm{N} \mathrm{l}^{-1}$ and $9.8 \mathrm{mg} \mathrm{PO}_{4}-\mathrm{P} \mathrm{l}^{-1}$ to investigate the plant's performance. Under the experimental conditions, $H$. portulacoides was able to retain $30 \%$ of $\mathrm{N}$ and $18 \%$ of $\mathrm{P}$ in the shoots and roots, and the average decrease of nitrate- $\mathrm{N}$ in the effluent was $29 \mathrm{mg} \mathrm{l}^{-1}$ and phosphate-P was $5 \mathrm{mg} \mathrm{l}^{-1}$, over a $5 \mathrm{wk}$ period. Moreover, 
a more recent study by Marques et al. (2017), published after the literature survey was completed, evaluated the capacity of $H$. portulacoides to extract DIN from an intensive RAS farm effluent. Average decrease in DIN was $65 \%$. In both studies, the plant was considered a suitable candidate for the remediation of aquaculture effluents.

A total of 16 studies addressed $H$. portulacoides physiology $(\mathrm{n}=4)$, phytoremediation $(\mathrm{n}=8)$, primary productivity $(\mathrm{n}=1)$ and secondary metabolites $(\mathrm{n}=$ 3), which contribute to highlight the potential of this halophyte species for IMTA (Fig. 6). This species is widely distributed throughout salt marsh ecosystems of the Mediterranean, Irano-Turanian and West Euro-Siberian, North American and South African regions (Waisel 1972, Castroviejo 1990). It plays an important role in the ecosystem services provided by coastal wetlands, namely in nutrient cycling and phytoremediation processes (Válega et al. 2008a, Sousa et al. 2010, 2011). Its distribution is correlated with good soil drainage, and it tolerates frequent short inundations as occurs in the intertidal zones where it thrives (Jensen 1985). It can cope and grow within a wide concentration range of dissolved $\mathrm{NaCl}$ in the water, from 0 to full strength seawater $\left(\sim 500 \mathrm{~mol} \mathrm{~m}^{-3}\right)$ and over (up to $1000 \mathrm{~mol} \mathrm{~m}^{-3}$ ) (Jensen 1985, Redondo-Gómez et al. 2007). Specialized

\section{Halimione}

portulacoides

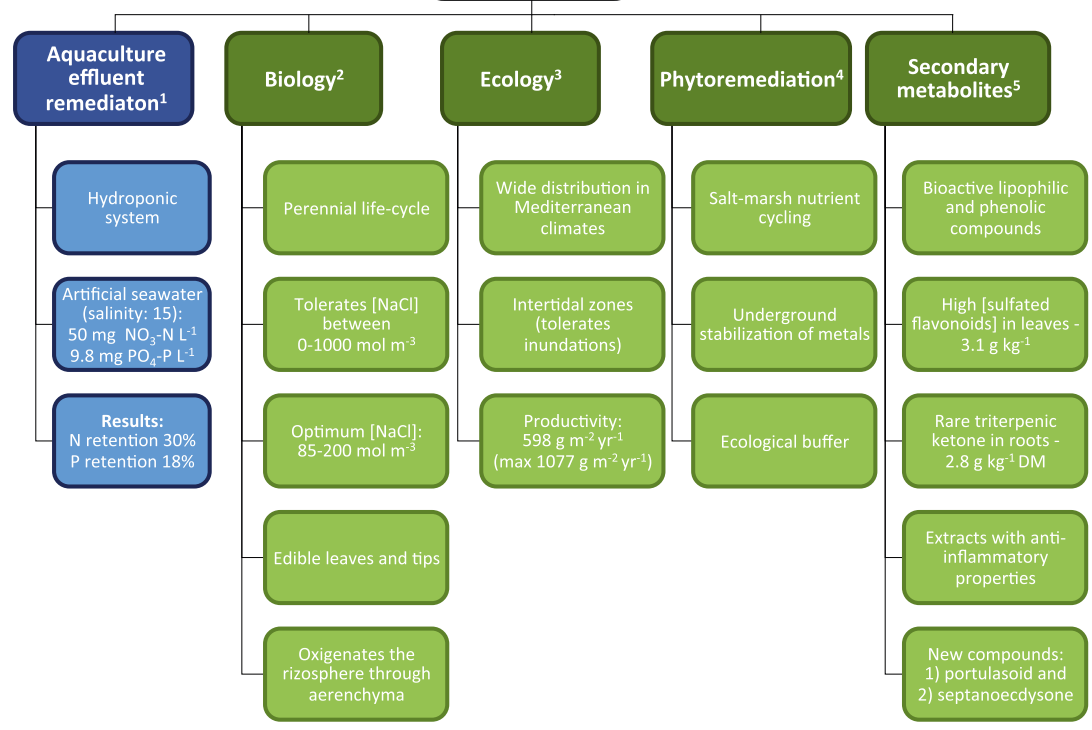

Fig. 6. Summary of Halimione portulacoides relevant characteristics found in the scientific literature: ${ }^{1}$ Buhmann et al. $2015 ;{ }^{2}$ Neves et al. 2007, Waisel 1972 ; ${ }^{3}$ Jensen 1985, Redondo-Gómez et al. (2007); ${ }^{4}$ Andrades-Moreno et al. (2013), Cambrollé et al. (2012a,b), Sousa et al. (2010, 2011), Válega et al. (2008a); ${ }^{5}$ Ben Nejma et al. (2015), Hill \& Connolly (2015), Rodrigues et al. (2014), Vilela et al. (2014) vacuoles within leaves are responsible for compartmentalizing $\mathrm{Na}^{+}$and $\mathrm{Cl}^{-}$which are further excreted through epidermal bladders, protecting the metabolic machinery from salt-induced stress (RedondoGómez et al. 2007, Benzarti et al. 2012, 2015, Shabala et al. 2014). Within the abovementioned spectrum of salinity, optimal growth was found at 85-200 mol $\mathrm{m}^{-3} \mathrm{NaCl}$ and a gradual depression was observed between 410 and $690 \mathrm{~mol} \mathrm{~m}^{-3} \mathrm{NaCl}$ (Jensen 1985, Redondo-Gómez et al. 2007). Nonetheless, growth is stimulated at higher $\mathrm{NaCl}$ concentrations with increasing concentrations of dissolved nitrate-N (Jensen 1985). At supra-optimal salinity levels, $\mathrm{Cl}^{-}$directly competes with $\mathrm{NO}_{3}{ }^{-}$uptake (Benzarti et al. 2015), explaining the positive impact of higher nitrate-N concentration at higher salinities. Moreover, decreased stomatal conductance is also observed with increasing $\mathrm{Na}^{+}$and $\mathrm{Cl}^{-}$concentrations (RedondoGómez et al. 2007, Flowers \& Colmer 2015), a mechanism that prevents water loss and modulates water transport to reduce net uptake of salts to the shoots (Ayala \& O'Leary 1995, Khan et al. 2001, Katschnig et al. 2013). In terms of primary production, Neves et al. (2007) conducted field studies in the south of Portugal and determined that mean above-ground biomass production was $598 \mathrm{~g} \mathrm{~m}^{-2} \mathrm{yr}^{-1}$, with maximum values registered in spring, reaching $1077 \mathrm{~g} \mathrm{~m}^{-2} \mathrm{yr}^{-1}$. In terms of biochemical composition, Vilela et al. (2014) screened for lipophilic and phenolic compounds with potential bioactivity and found that lipophilic fractions of leaves and stems are mainly composed of long chain aliphatic acids and alcohols and smaller quantities of sterols. Also, they identified 13 phenolic compounds with higher concentration in the leaves (4.6 $\mathrm{g} \mathrm{kg}^{-1}$ dry matter [DM]), from which $3.1 \mathrm{~g} \mathrm{~kg}^{-1} \mathrm{DM}$ were sulfated flavonoids. A rare triterpenic ketone with pharmaceutical properties (Hill \& Connolly 2015) was found at high concentrations ( $\left.2.8 \mathrm{~g} \mathrm{~kg}^{-1} \mathrm{DM}\right)$ in the roots, namely the molecule hop17(21)-en-3-one (Vilela et al. 2014). Rodrigues et al. (2014) looked at the bioactivity of $H$. portulacoides extracts and found high radical scavenging activity (IC50 $=0.9 \mathrm{mg} \mathrm{ml}^{-1}$ ) against the radical ABTS and a decrease in nitric oxide production after incubation of macrophages with lipopolysaccharide and a chloroform extract 
$\left(\mathrm{IC} 50=109 \mu \mathrm{g} \mathrm{ml}^{-1}\right)$, indicative of anti-inflammatory properties. More recently, 2 new bioactive compounds designated as 'portulasoid' and 'septanoecdysone' were isolated from the plant (Ben Nejma et al. 2015).

This species has also been studied for its high regeneration potential and its remarkable metal phytoremediation capacities, which include stabilization, at the root level, of toxic inorganic substances and extraction and retention of several compounds in above-ground biomass (Sousa et al. 2008, 2010, 2011, Válega et al. 2008a,b, Cambrollé et al. 2012a,b, Andrades-Moreno et al. 2013). These processes occur without compromising key metabolic sites and reinforce its role as an ecological buffer, helping maintain the homeostasis of the salt marsh ecosystem.

The physiological adaptations to salt marsh environments and phytoremediation potential of $H$. portulacoides make this species a good candidate to mitigate potential negative impacts promoted by marine aquaculture effluents, as demonstrated so far. By being exposed to numerous abiotic stresses, these plants are expected to cope with multiple stressinducing factors that fluctuate on a short-term scale, reinforcing their suitability for IMTA (Walker et al. 2014, Lutts \& Lefèvre 2015). Moreover, H. portulacoides is widely distributed geographically, with an apparent good productivity (Neves et al. 2007) and can be easily propagated through cuttings, and therefore its use at a large scale is not dependent on wild populations for the harvesting of seeds (Sousa et al. 2010).

Additionally, halophytes have shown a positive correlation between increasing salinity and production of secondary metabolites (Aquino et al. 2011, Benzarti et al. 2012, Buhmann \& Papenbrock 2013a) and enhanced production of phenols and flavonoids during the flowering period (Medini et al. 2011, Jallali et al. 2012), allowing for the manipulation of such molecules within the plant. The leaves of $H$. portulacoides have high average levels of sulfated flavonoids (Vilela et al. 2014), therefore being a potential source of these compounds of pharmacological interest (Correia-da-Silva et al. 2014). For instance, Flaveria bidentis (L.) Kuntze is recognized as a good source of sulfated flavonoids, namely isorhamnetin 3-sulfate, with about $744 \mathrm{mg} \mathrm{kg}^{-1} \mathrm{DM}$ (Xie et al. 2012), only $1 / 4$ of the content exhibited by H. portulacoides. Moreover, long chain chloroalkanes were also recorded in leaf waxes (Grossi \& Raphel 2003) and volatile organic compounds in root exudates (Oliveira et al. 2012). A rare bioactive triterpenic ketone extracted from the roots of this halophyte (Vilela et al. 2014) further elevates the pharmacological interest of this species, and it is likely that future biochemical studies using omicsapproaches will reveal new bioactive compounds of interest. Furthermore, by presenting edible leaves and tips, this halophyte may actively contribute to the diversification and expansion of the sea vegetable market.

The potential of $H$. portulacoides to be used as a halophyte biofilter is undeniable, yet little information is available relative to its use and performance. In order to explore its suitability, additional data are required on its planting density, hydraulic regimes, growth medium, nutrient requirements and availability and how these affect growth performance, nutrient uptake, phytoremediation efficiency and biochemical composition. Both CWs and hydroponics modules should be tested in order to find out which growing system is the best for the species.

\section{PRESENT SETBACKS AND FUTURE OPPORTUNITIES}

Aquaculture continues to be the fastest-growing industry in the animal food-producing sector, and its sustainability has been a major source of discussion (Troell et al. 2014, FAO 2016). In many regions of the world, including several southern European countries, a significant part of the aquaculture industry is based on semi-intensive farming practices, which are in their essence more sustainable than intensive/ super-intensive productions (Bunting 2013, Edwards 2015). Nonetheless, economic issues are a setback to the expansion of those production models, usually related to the price of the end product (which competes in the market with intensively produced ones), the slower capital return and stakeholders' perceptions (FAO 2016). These limit investment and result in the lack of innovation in system design and process optimization. Additionally, promotion of public awareness and political support of these production systems are needed (Feucht \& Zander 2015, Bostock et al. 2016).

One of the main challenges faced by these aquaculture practices is how to increase their competitiveness while maintaining their more ecological modes of seafood production. A new focus on product differentiation and certification, highlighting its origin, sustainability, quality and health benefits, will likely be the only pathway to balance economic and environmental tradeoffs of semi-intensive aquaculture and drive investment. In this context, future studies 
using Halimione portulacoides as an aquatic biofilter will generate valuable insights on the integration of halophytes in IMTA, contributing to the diversification of aquaculture and sustainable food production.

Besides the technical and biological features of IMTA, research also needs to address social and economic aspects. For IMTA to attain its true potential, it needs to be socially accepted, and satisfying key stakeholders will be paramount for business success and resilience (Alexander et al. 2016, Chopin 2017). The relatively low number of studies exploring these questions usually addressed consumers' perspectives, and it is now evident that they lack knowledge on aquaculture species and production methods, including IMTA (Shuve et al. 2009, Barrington et al. 2010). Yet, consumers do recognize socio-economic benefits from aquaculture and are concerned with sustainability issues (Whitmarsh \& Palmieri 2009, Barrington et al. 2010, Fernandez-Polanco \& Luna 2012). Aquaponics, for example, is regarded as the fittest land-based IMTA for sustainable urban farming (Specht et al. 2014), and a European consumer survey about that mode of production found a positive attitude towards local products (Milicic et al. 2017). In the same study, willingness to pay regarding food was mostly based on price and whether the products are free of antibiotics, pesticides and herbicides. This type of study provides valuable guidance concerning marketing efforts that, in this specific case, should be directed towards local shops and restaurants, emphasizing sustainable and organicbased food production (Goddek et al. 2015). A recent study about European stakeholders' perspectives on IMTA, which included industry actors, policy makers, fishermen and other users of the marine environment, found they positively discriminated IMTA in terms of environmental benefits, creation of new income streams and improvement of the overall negative public image of aquaculture (Alexander et al. 2016). Moreover, IMTA systems can incorporate additional sources of profit, including tourism and educational activities. Junge et al. (2017) outlined that a multi-disciplinary approach to aquaponics is essential to its success, and additional actors other than biologists and engineers, such as designers, architects, social and health/nutritional scientists, would be important propellers for the socio-economic valorization of the activity. More multidimensional valuation studies are needed to assess not only the economic potential of IMTA in general and halophytes in particular, but also the ecological and social benefits they can provide in order to fully understand the scope of IMTA in the future of aquaculture.
Acknowledgements. We thank the Portuguese Foundation for Science and Technology (FCT) for financial support of this study through a PhD grant to M.C. (PD/BD/127990/ 2016) and to CESAM (UID/AMB/50017/2013), and the cofunding by FEDER, within the PT2020 Partnership Agreement and Compete 2020. This work was also supported by the Integrated Program of SR\&TD 'Smart Valorization of Endogenous Marine Biological Resources Under a Changing Climate' (reference Centro-01-0145-FEDER-000018), co-funded by Centro 2020 program, Portugal 2020, European Union, through the European Regional Development Fund.

\section{LITERATURE CITED}

Abideen Z, Ansari R, Khan MA (2011) Halophytes: potential source of ligno-cellulosic biomass for ethanol production. Biomass Bioenergy 35:1818-1822

Abreu MH, Pereira R, Yarish C, Buschmann AH, SousaPinto I (2011) IMTA with Gracilaria vermiculophylla: productivity and nutrient removal performance of the seaweed in a land-based pilot scale system. Aquaculture 312:77-87

Alexander KA, Angel D, Freeman S, Israel D and others (2016) Improving sustainability of aquaculture in Europe: stakeholder dialogues on IMTA. Environ Sci Policy 55: 96-106

Andrades-Moreno L, Cambrollé J, Figueroa ME, MateosNaranjo E (2013) Growth and survival of Halimione portulacoides stem cuttings in heavy metal contaminated soils. Mar Pollut Bull 75:28-32

Aquino RS, Grativol C, Mourão PAS (2011) Rising from the sea: correlations between sulfated polysaccharides and salinity in plants. PLOS ONE 6:e18862

Ayala F, O'Leary JW (1995) Growth and physiology of Salicornia bigelovii Torr. at suboptimal salinity. Int J Plant Sci 156:197-205

* Bannister RJ, Valdemarsen T, Hansen PK, Holmer M, Ervik A (2014) Changes in benthic sediment conditions under an Atlantic salmon farm at a deep, well-flushed coastal site. Aquacult Environ Interact 5:29-47

*Barreira L, Resek E, Rodrigues MJ, Rocha MI and others (2017) Halophytes: gourmet food with nutritional health benefits? J Food Compos Anal 59:35-42

*Barrington K, Ridler N, Chopin T, Robinson S, Robinson B (2010) Social aspects of the sustainability of integrated multi-trophic aquaculture. Aquacult Int 18:201-211

Ben Nejma A, Nguir A, Ben Jannet H, Hamza MA, Daïch A, Othman M, Lawson AM (2015) New septanoside and 20hydroxyecdysone septanoside derivative from Atriplex portulacoides roots with preliminary biological activities. Bioorg Med Chem Lett 25:1665-1670

Benzarti M, Rejeb KB, Debez A, Messedi D, Abdelly C (2012) Photosynthetic activity and leaf antioxidative responses of Atriplex portulacoides subjected to extreme salinity. Acta Physiol Plant 34:1679-1688

* Benzarti M, Rejeb KB, Messedi D, Abdelly C, Debez A (2015) Involvement of nitrogen in salt resistance of Atriplex portulacoides is supported by split-root experiment data and exogenous application of N-rich compounds. J Plant Nutr Soil Sci 178:312-319

Boer B (2008) Halophyte research and development: What needs to be done next? In: Khan MA, Weber DJ (eds) Ecophysiology of high salinity tolerant plants. Tasks for 
Vegetation Science 40. Springer, Dordrecht, p 397-399 Bostock J, Lane A, Hough C, Yamamoto K (2016) An assessment of the economic contribution of EU aquaculture production and the influence of policies for its sustainable development. Aquacult Int 24:699-733

Boughalleb F, Denden M (2011) Physiological and biochemical changes of two halophytes, Nitraria retusa (Forssk.) and Atriplex halimus (L.) under increasing salinity. Agric J 6:327-339

Boxman SE, Nystrom M, Capodice JC, Ergas SJ, Main KL, Trotz MA (2017) Effect of support medium, hydraulic loading rate and plant density on water quality and growth of halophytes in marine aquaponic systems. Aquacult Res 48:2463-2477

Brown JJ, Glenn EP, Fitzsimmons KM, Smith SE (1999) Halophytes for the treatment of saline aquaculture effluent. Aquaculture 175:255-268

Buhmann A, Papenbrock J (2013a) An economic point of view of secondary compounds in halophytes. Funct Plant Biol 40:952-967

Buhmann A, Papenbrock J (2013b) Biofiltering of aquaculture effluents by halophytic plants: basic principles, current uses and future perspectives. Environ Exp Bot 92:122-133

Buhmann A, Waller U, Wecker B, Papenbrock J (2015) Optimization of culturing conditions and selection of species for the use of halophytes as biofilter for nutrient-rich saline water. Agric Water Manag 149:102-114

Bunting SW (2013) Principles of sustainable aquaculture: promoting social, economic and environmental resilience. Routledge, Abingdon

* Cambrollé J, Mancilla-Leytón JM, Muñoz-Vallés S, Luque T, Figueroa ME (2012a) Tolerance and accumulation of copper in the salt-marsh shrub Halimione portulacoides. Mar Pollut Bull 64:721-728

Cambrollé J, Mancilla-Leytón JM, Muñoz-Vallés S, Luque T, Figueroa ME (2012b) Zinc tolerance and accumulation in the salt-marsh shrub Halimione portulacoides. Chemosphere 86:867-874

Carballeira T, Ruiz I, Soto M (2016) Effect of plants and surface loading rate on the treatment efficiency of shallow subsurface constructed wetlands. Ecol Eng 90:203-214

Castroviejo S (1990) Halimione Aellen. In: Castroviejo S, Aedo C, Laínz M, Muñoz Garmendia F, Nieto Feliner G, Paiva J, Benedí C (eds) Flora Iberica 2. Real Jardín Botánico, CSIC, Madrid, p 513-515

Chen RZ, Wong MH (2016) Integrated wetlands for food production. Environ Res 148:429-442

Chopin T (2015) Marine aquaculture in Canada: wellestablished monocultures of finfish and shellfish and an emerging integrated multi-trophic aquaculture (IMTA) approach including seaweeds, other invertebrates, and microbial communities. Fisheries 40:28-31

Chopin T (2017) Challenges of moving integrated multitrophic aquaculture along the R\&D and commercialization continuum in the western world. J Ocean Technol $12: 34-47$

Correia-da-Silva M, Sousa E, Pinto MMM (2014) Emerging sulfated flavonoids and other polyphenols as drugs: nature as an inspiration. Med Res Rev 34:223-279

de Lange HJ, Paulissen MPCP (2016) Efficiency of three halophyte species in removing nutrients from saline water: a pilot study. Wetlands Ecol Manag 24:587-596

de Lange HJ, Paulissen MPCP, Slim PA (2013) 'Halophyte filters': the potential of constructed wetlands for applica- tion in saline aquaculture. Int J Phytoremediation 15: 352-364

dos Santos MJPL (2016) Smart cities and urban areasaquaponics as innovative urban agriculture. Urban For Urban Green 20:402-406

Edwards P (2015) Aquaculture environment interactions: past, present and likely future trends. Aquaculture 447: $2-14$

European Commission (1992) Council Directive 92/43/EEC of 21 May 1992 on the conservation of natural habitats and of wild fauna and flora. Off J Eur Comm 206/16 (22.7.92)

European Commission (2012) Blue growth. Opportunities for marine and maritime sustainable growth. Publications Office of the European Union, Brussels

European Commission (2013) Interpretation manual of European Union habitats - EUR28. Nature ENV B.3. Directorate General Environment, Brussels

European Commission (2015) Closing the loop-an EU action plan for the circular economy. European Commission Secretariat, Brussels

European Environment Agency (2016) Seafood in Europea food system approach for sustainability. Publications Office of the European Union, Copenhagen

*Fang J, Zhang J, Xiao T, Huang D, Liu S (2016) Integrated multi-trophic aquaculture (IMTA) in Sanggou Bay, China. Aquacult Environ Interact 8:201-205

FAO (Food and Agriculture Organization of the United Nations) (2016) The state of world fisheries and aquaculture. Contributing to food security and nutrition for all. FAO, Rome

Fernandez-Polanco J, Luna L (2012) Factors affecting consumers' beliefs about aquaculture. Aquacult Econ Manag 16:22-39

* Feucht Y, Zander K (2015) Of earth ponds, flow-through and closed recirculation systems - German consumers' understanding of sustainable aquaculture and its communication. Aquaculture 438:151-158

Flowers TJ, Colmer TD (2008) Salinity tolerance in halophytes. New Phytol 179:945-963

Flowers TJ, Colmer TD (2015) Plant salt tolerance: adaptations in halophytes. Ann Bot 115:327-331

Flowers TJ, Hajibagheri MA, Clipson NJW (1986) Halophytes. Q Rev Biol 61:313-337

F Flowers TJ, Galal HK, Bromham L (2010) Evolution of halophytes: multiple origins of salt tolerance in land plants. Funct Plant Biol 37:604-612

Glenn EP, Brown JJ, Blumwald E (1999) Salt tolerance and crop potential of halophytes. Crit Rev Plant Sci 18: $227-255$

KGoddek S, Delaide B, Mankasingh U, Ragnarsdottir KV, Jijakli H, Thorarinsdottir R (2015) Challenges of sustainable and commercial aquaponics. Sustainability 7 : 4199-4224

F Goddek S, Espinal CA, Delaide B, Jijakli MH, Schmautz Z, Wuertz S, Keesman KJ (2016) Navigating towards decoupled aquaponic systems: a system dynamics design approach. Water 8:303

*Graber A, Junge R (2009) Aquaponic systems: nutrient recycling from fish wastewater by vegetable production. Desalination 246:147-156

Granada L, Sousa N, Lopes S, Lemos MFL (2016) Is integrated multitrophic aquaculture the solution to the sectors' major challenges?-a review. Rev Aquacult 8: 283-300 
Grand View Research (2016) Commercial seaweed market analysis by product (brown seaweed, red seaweed, green seaweed), by form (liquid, powdered, flakes), by application (agriculture, animal feed, human consumption) and segment forecasts to 2024. Available at: www.grandviewresearch.com/industry-analysis/commercial-seaweed-market (accessed 19 May 2017)

* Grossi V, Raphel D (2003) Long-chain (C19-C29) 1-chloro$\mathrm{n}$-alkanes in leaf waxes of halophytes of the Chenopodiaceae. Phytochemistry 63:693-698

Gunning D, Maguire J, Burnell G (2016) The development of sustainable saltwater-based food production systems: a review of established and novel concepts. Water 8: 598

*Hadad HR, Maine MA, Bonetto CA (2006) Macrophyte growth in a pilot-scale constructed wetland for industrial wastewater treatment. Chemosphere 63:1744-1753

Hill RA, Connolly JD (2015) Triterpenoids. Nat Prod Rep 32: 273-327

Hughes AD, Black KD (2016) Going beyond the search for solutions: understanding trade-offs in European integrated multi-trophic aquaculture development. Aquacult Environ Interact 8:191-199

Imfeld G, Braeckevelt M, Kuschk P, Richnowa HH (2009) Monitoring and assessing processes of organic chemicals removal in constructed wetlands. Chemosphere 74 : 349-362

Isca VMS, Seca AM, Pinto DC, Silva H, Silva AM (2014) Lipophilic profile of the edible halophyte Salicornia ramosissima. Food Chem 165:330-336

Jallali I, Megdiche W, M'Hamdi B, Oueslati S, Smaoui A, Abdelly C, Ksouri R (2012) Changes in phenolic composition and antioxidant activities of the edible halophyte Crithmum maritimum L. with physiological stage and extraction method. Acta Physiol Plant 34:1451-1459

Jensen A (1985) On the ecophysiology of Halimione portulacoides. Plant Ecol 61:231-240

Junge R, König B, Villarroel M, Komives T, Haïssam Jijakli $M(2017)$ Strategic points in aquaponics. Water 9:182

Kadereit G, Mavrodiev EV, Zacharias EH, Sukhorukov AP (2010) Molecular phylogeny of Atripliceae (Chenopodioideae, Chenopodiaceae): implications for systematics, biogeography, flower and fruit evolution, and the origin of C4 photosynthesis. Am J Bot 97:1664-1687

Katschnig D, Broekman R, Rozema J (2013) Salt tolerance in the halophyte Salicornia dolichostachya moss: growth, morphology and physiology. Environ Exp Bot 92:32-42

Khan MA, Gul B, Weber DJ (2001) Effect of salinity on the growth and ion content of Salicornia rubra. Commun Soil Sci Plant Anal 32:2965-2977

Kim DH, Kim TH (2013) Salicornia spp.-derived salt and its production process. US 8420152 B2

Kloas W, Groß R, Baganz D, Graupner J and others (2015) A new concept for aquaponic systems to improve sustainability, increase productivity, and reduce environmental impacts. Aquacult Environ Interact 7:179-192

Ksouri R, Ksouri WM, Jallali I, Debez A, Magné C, Hiroko I, Abdelly C (2012) Medicinal halophytes: potent source of health promoting biomolecules with medical, nutraceutical and food applications. Crit Rev Biotechnol 32: 289-326

Lin YF, Jing SR, Wang TW, Lee DY (2002a) Effects of macrophytes and external carbon sources on nitrate removal from groundwater in constructed wetlands. Environ Pollut 119:413-420
Lin YF, Jing SR, Lee DY, Wang TW (2002b) Nutrient removal from aquaculture wastewater using a constructed wetlands system. Aquaculture 209:169-184

* Lin YF, Jing SR, Lee DY (2003) The potential use of constructed wetlands in a recirculating aquaculture system for shrimp culture. Environ Pollut 123:107-113

* Lin YF, Jing SR, Lee DY, Chang YF, Chen YM, Shih KC (2005) Performance of a constructed wetland treating intensive shrimp aquaculture wastewater under high hydraulic loading rate. Environ Pollut 134:411-421

Ku D, Zhang M, Wang S, Cai J, Zhou X, Zhu C (2010) Nutritional characterization and changes in quality of Salicornia bigelovii Torr. during storage. Lebensm Wiss Technol 43:519-524

Lüderitz V, Gerlach F (2002) Phosphorus removal in different constructed wetlands. Acta Biotechnol 22:91-99

* Lupatsch I, Kissil GW (1998) Predicting aquaculture waste from gilthead seabream (Sparus aurata) culture using a nutritional approach. Aquat Living Resour 11:265-268

* Lutts S, Lefèvre I (2015) How can we take advantage of halophyte properties to cope with heavy metal toxicity in salt-affected areas? Ann Bot 115:509-528

* Lymbery AJ, Doupé RG, Bennett T, Starcevich MR (2006) Efficacy of a subsurface-flow wetland using the estuarine sedge Juncus kraussii to treat effluent from inland saline aquaculture. Aquacult Eng 34:1-7

* Lymbery AJ, Kay GD, Doupé RG, Partridge GJ, Norman HC (2013) The potential of a salt-tolerant plant (Distichlis spicata cV. NyPa Forage) to treat effluent from inland saline aquaculture and provide livestock feed on salt-affected farmland. Sci Total Environ 445-446: 192-201

*Maciel E, Leal MC, Lillebø AI, Domingues P, Domingues MR, Calado R (2016) Bioprospecting of marine macrophytes using MS-based lipidomics as a new approach. Mar Drugs 14:49

Marques B, Calado R, Lillebø AI (2017) New species for the biomitigation of a super-intensive marine fish farm effluent: combined use of polychaete-assisted sand filters and halophyte aquaponics. Sci Total Environ 599-600: 1922-1928

Medini F, Ksouri R, Falleh H, Megdiche W, Trabelsi N, Abdelly C (2011) Effects of physiological stage and solvent on polyphenol composition, antioxidant and antimicrobial activities of Limonium densiflorum. J Med Plants Res 5:6719-6730

Milicic V, Thorarinsdottir R, dos Santos M, Hancic MT (2017) Commercial aquaponics approaching the European market: to consumers' perceptions of aquaponics products in Europe. Water 9:80

Mozdzer TJ, Zieman JC, McGlathery KJ (2010) Nitrogen uptake by native and invasive temperate coastal macrophytes: importance of dissolved organic nitrogen. Estuaries Coasts 33:784-797

*Neori A, Chopin T, Troell M, Buschmann AH and others (2004) Integrated aquaculture: rationale, evolution and state of the art emphasizing seaweed biofiltration in modern mariculture. Aquaculture 231:361-391

*Neves JP, Ferreira LF, Simões MP, Gazarini LC (2007) Primary production and nutrient content in two salt marsh species, Atriplex portulacoides L. and Limoniastrum monopetalum L., in Southern Portugal. Estuaries Coasts 30:459-468

* Oliveira V, Santos AL, Aguiar C, Santos L and others (2012) Prokaryotes in salt marsh sediments of Ria de Aveiro: 
effects of halophyte vegetation on abundance and diversity. Estuar Coast Shelf Sci 110:61-68

Panta S, Flowers T, Lane P, Doyle R, Haros G, Shabala S (2014) Halophyte agriculture: success stories. Environ Exp Bot 107:71-83

Quintã R, Santos R, Thomas DN, Le Vay L (2015a) Growth and nitrogen uptake by Salicornia europaea and Aster tripolium in nutrient conditions typical of aquaculture wastewater. Chemosphere 120:414-421

Quintã R, Hill PW, Jones DL, Santos R, Thomas DN, Le Vay L (2015b) Uptake of an amino acid (alanine) and its peptide (trialanine) by the saltmarsh halophytes Salicornia europaea and Aster tripolium and its potential role in ecosystem $\mathrm{N}$ cycling and marine aquaculture wastewater treatment. Ecol Eng 75:145-154

Redondo-Gómez S, Mateos-Naranjo E, Davy AJ, Fernández-Muñoz F, Castellanos EM, Luque T, Figueroa ME (2007) Growth and photosynthetic responses to salinity of the salt-marsh shrub Atriplex portulacoides. Ann Bot 100:555

Rodrigues MJ, Gangadhar KN, Vizetto-Duarte C, Wubshet SG and others (2014) Maritime halophyte species from southern Portugal as sources of bioactive molecules. Mar Drugs 12:2228

Sanz-Lázaro C, Belando MD, Marín-Guirao L, NavarreteMier F, Marína A (2011) Relationship between sedimentation rates and benthic impact on Maërl beds derived from fish farming in the Mediterranean. Mar Environ Res 71:22-30

Sarà G, Lo Martire M, Sanfilippo M, Pulicanò G and others (2011) Impacts of marine aquaculture at large spatial scales: evidences from $\mathrm{N}$ and $\mathrm{P}$ catchment loading and phytoplankton biomass. Mar Environ Res 71:317-324

Science for Environment Policy (2015) Future brief: sustainable aquaculture. European Commission DG Environment by the Science Communication Unit, Bristol

Shabala S, Bose J, Hedrichemail R (2014) Salt bladders: Do they matter? Trends Plant Sci 19:687-691

Sharma R, Wungrampha S, Singh V, Pareek A, Sharma MK (2016) Halophytes as bioenergy crops. Front Plant Sci 7: 1372

Shelef O, Gross A, Rachmilevitch S (2013) Role of plants in a constructed wetland: current and new perspectives. Water 5:405-419

Shpigel M, Ben-Ezra D, Shauli L, Sagi M, Ventura V, Samocha T, Lee JJ (2013) Constructed wetland with Salicornia as a biofilter for mariculture effluents. Aquaculture 412-413:52-63

Shuve H, Caines E, Ridler N, Chopin T and others (2009) Survey finds consumers support integrated multi-trophic aquaculture: effective marketing concept key. Glob Aquac Advocate 2009:22-23

Somerville C, Cohen M, Pantanella E, Stankus A, Lovatelli A (2014) Small-scale aquaponic food production. Integrated fish and plant farming. Fish Aquac Tech Pap 589. FAO, Rome

Sousa AI, Caçador I, Lillebø AI, Pardal MA (2008) Heavy metal accumulation in Halimione portulacoides: intraand extra-cellular metal binding sites. Chemosphere 70 : 850-857

Sousa AI, Lillebø AI, Pardal MA, Caçador I (2010) Productivity and nutrient cycling in salt marshes: contribution to ecosystem health. Estuar Coast Shelf Sci 87:640-646

Sousa AI, Lillebø AI, Pardal MA, Caçador I (2011) Influence of multiple stressors on the auto-remediation processes occurring in salt marshes. Mar Pollut Bull 62:1584-1587

F specht K, Siebert R, Hartmann I, Freisinger UB and others (2014) Urban agriculture of the future: an overview of sustainability aspects of food production in and on buildings. Agric Human Values 31:33-51

Stewart GR, Lee JA, Orebamjo TO (1973) Nitrogen metabolism of halophytes II. Nitrate availability and utilization. New Phytol 72:539-546

* Troell M, Naylor RL, Metian M, Beveridge M and others (2014) Does aquaculture add resilience to the global food system? Proc Natl Acad Sci USA 111:13257-13263

* Troell M, Joyce A, Chopin T, Neori A, Buschmann AH, Fang JG (2009) Ecological engineering in aquaculturepotential for integrated multi-trophic aquaculture (IMTA) in marine offshore systems. Aquaculture 297:1-9

* Turcios AE, Papenbrock J (2014) Sustainable treatment of aquaculture effluents - What can we learn from the past for the future? Sustainability 6:836-856

V Valdemarsen T, Bannister RJ, Hansen PK, Holmer M, Ervik A (2012) Biogeochemical malfunctioning in sediments beneath a deep-water fish farm. Environ Pollut 170: $15-25$

*Válega M, Lillebø AI, Pereira ME, Caçador I, Duarte AC, Pardal MA (2008a) Mercury in salt marshes ecosystems: Halimione portulacoides as biomonitor. Chemosphere 73:1224-1229

*Válega M, Lillebø AI, Caçador I, Pereira ME, Duarte AC, Pardal MA (2008b) Mercury mobility in a salt marsh colonised by Halimione portulacoides. Chemosphere 72 : 1607-1613

*Ventura Y, Wuddineh WA, Myrzabayeva M, Alikulov Z and others (2011a) Effect of seawater concentration on the productivity and nutritional value of annual Salicornia and perennial Sarcocornia halophytes as leafy vegetable crops. Sci Hortic (Amst) 128:189-196

*Ventura Y, Wuddineh WA, Shpigel M, Samocha TM and others (2011b) Effects of day length on flowering and yield production of Salicornia and Sarcocornia species. Sci Hortic (Amst) 130:510-516

*Ventura Y, Sagi M (2013) Halophyte crop cultivation: the case for Salicornia and Sarcocornia. Environ Exp Bot 92: 144-153

V Ventura Y, Eshel A, Pasternak D, Sagi M (2015) The development of halophyte-based agriculture: past and present. Ann Bot 115:529-540

*Verhoeven JT, Meuleman AF (1999) Wetlands for wastewater treatment: opportunities and limitations. Ecol Eng 12:5-12

Vilela C, Santos SAO, Coelho D, Silva AMS, Freire CSR, Neto CP, Silvestre AJD (2014) Screening of lipophilic and phenolic extractives from different morphological parts of Halimione portulacoides. Ind Crops Prod 52:373-379

*Vymazal J (2010) Constructed wetlands for wastewater treatment. Water 2:530-549

* Vymazal J (2011) Plants used in constructed wetlands with horizontal subsurface flow: a review. Hydrobiologia 674: 133-156

Waisel Y (1972) Biology of halophytes. Academic Press, New York, NY

* Walker DJ, Lutts S, Sánchez-García M, Correal E (2014) Atriplex halimus L.: its biology and uses. J Arid Environ 100-101:111-121

* Waller U, Buhmann AK, Ernst A, Hanke V and others (2015) Integrated multi-trophic aquaculture in a zero-exchange recirculation aquaculture system for marine fish and 
hydroponic halophyte production. Aquacult Int 23: 1473-1489

Wang X, Olsen LM, Reitan KI, Olsen Y (2012) Discharge of nutrient wastes from salmon farms: environmental effects, and potential for integrated multi-trophic aquaculture. Aquacult Environ Interact 2:267-283

Webb JM, Quintã R, Papadimitriou S, Norman L, Rigby M, Thomas DN, Le Vay L (2012) Halophyte filter beds for treatment of saline wastewater from aquaculture. Water Res 46:5102-5114

Webb JM, Quintã R, Papadimitriou S, Norman L, Rigby M, Thomas DN, Le Vay L (2013) The effect of halophyte planting density on the efficiency of constructed wet-

Editorial responsibility: Adam Hughes,

Oban, UK lands for the treatment of wastewater from marine aquaculture. Ecol Eng 61:145-153

*Weber DJ, Ansari R, Gul B, Khan MA (2007) Potential of halophytes as source of edible oil. J Arid Environ 68: 315-321

* Whitmarsh D, Palmieri MG (2009) Social acceptability of marine aquaculture: the use of survey-based methods for eliciting public and stakeholder preferences. Mar Policy 33:452-457

Xie Q, Yin L, Zhang G, Wei Y (2012) Separation and purification of isorhamnetin 3-sulphate from Flaveria bidentis (L.) Kuntze by counter-current chromatography comparing two kinds of solvent systems. J Sep Sci 35:159-165

Submitted: February 10, 2017; Accepted: September 20, 2017 Proofs received from author(s): November 9, 2017 